\title{
REMEDIAL READING PROGRAM OF AUF-CED: BEST PRACTICES AND IMPACT
}

\author{
Elvira S. Balinas, Ph. D., \\ Angeles University Foundation \\ Angeles City, Philippines \\ Janette R. Rodriguez Ph.D, \\ Angeles University Foundation \\ Angeles City, Philippines
}

\author{
Jennifer P. Santillan, MAEd, \\ Angeles University Foundation \\ Angeles City, Philippines \\ Yolanda C. Valencia, MAEd \\ Angeles University Foundation \\ Angeles City, Philippines
}

\begin{abstract}
The educational systems, commissioned by the Constitution, shall reach out to nearby communities by participating in local and national societies' civic programs. The Angeles University Foundation-College of Education (AUF-CED), a Center of Excellence (COE)-recognized institution, realizes that literacy education should be delivered and integrated through community extension to enhance personnel's capacity building by extending expertise to the partner community. In effect, using Qualitative Reading Inventory (QRI-5) by Leslie and Caldwell (2011), this study described the best practices of AUF-CED's remedial reading program implementing procedure and evaluated its impact among267 pupil-respondents' reading performance categorized under frustration level as indicated by difficulty in decoding, word recognition, miscues, slow reading speed, and poor comprehension. Findings revealed the program's favorable impact on participants' reading performance as evidenced by the significant differences in the pretest and posttest results. Lack of significant difference in the miscues committed and the reading speed could be attributed to program's short span and tutees' absenteeism. Recommendations include project's sustainability and improvement and provision of well-planned and implemented trainings to have greater impact on the clienteles and the community.
\end{abstract}

\section{Key words: best practices, reading remediation, frustration level, reading performance}

\section{INTRODUCTION}

The world's population has increased radically throughout the years. As of 2017, the Philippines alone, a country in the Southeast Asian region, has a total populace of $103,796,832$ which is projected to surge at about $109,947,900$ in 2020 . Amidst its growing number of people, the Philippine government has remained steadfast to convert dense population into productive and literate individuals, the pillar of a strong nation. In connection, the officer-incharge (OIC) of the Department of Education (DepEd) Literacy Coordinating Council, Dr. Dina Joana Ocampo, highlighted that literacy empowers people to become responsive and worthy individuals for their own personal development that will later be translated into valuable contributions to the community, the nation, and the world[1].

In the Philippines, developing among its people literacy skills or the ability to read and write is a top priority. The attainment of this goal is evidenced by the results of the surveys in 2015 revealing youth literacy rate of $98.2 \%$, up from $98.1 \%$ in 2013 and the adult literacy level of $96.6 \%$ which is higher than 96.4 $\%$ in 2013. These data indicate that significant gains in literacyhave been achieved brought about by various factors that contribute to the improvement of literacy status in the country [2].

The nation celebrates combined efforts of government, organizations or even private individuals to promote literacy.Undoubtedly, education plays a unique role in literacy development. According to the United Nations Educational, Scientific, and Cultural Organization (UNESCO) [3], literacy transitions are linked to growth in education. Similarly, improved literacy rates in the country can be attributed to the formalization and expansion of the educational system and its success in attaining its fundamental goal of developing students' literacy skills.

Various educational institutions in the country recognize their significant roles in building a strong nation through literacy. As a response to the United Nations Millennium Development Goals and the Education For All (EFA) 2015, the Philippines created the EFA 2015 National Action Plan, "Functionally Literate Filipinos: An Educated Nation," which aims to improve literacy levels, produce remarkable learning outcomes and strengthen education institutions [4] .

Although education signifies a unique impact in leveling the playing field for learners worldwide, the 
fact that illiteracy still exists cannot be simply ignored. According to the United Nations International Children's Emergency Fund (UNICEF)[5], worldwide, nearly 900 million people cannot read or write. Moreover, the number of children who do not attend school has increased tremendously and a significant proportion of those who go to school do not learn enough. Specifically, almost two in five learners who finish primary school have not learned how to read, write or do simple arithmetic.

In the Philippines, a recent study revealed that there are at least 1.2 million five to fifteen year- old out-of-school youth. Another study disclosed alarmingly low learning outcomes for 5-year old kindergarten children in conflict-affected areas in Mindanao. In 2015, Philippines in general, has 349,974 cases of youth illiteracy whereas adult illiteracy accounts for 2.32 million [2].

As of 2015, the DepEd, which is responsible for basic education, is composed of 46, 404 schools; 38,659 of which are public while 7,745 are private. In the secondary level or grades 7 to 12 , among the 12,878 schools, 7,748 of them are public whereas 5,130 are private. These schools facilitate literacy development among all learners through the formal curriculum. In addition, they integrate intervention programs to cater to the needs of some students who need special attention in terms of literacy. In particular, they conduct half-day remediation program on a weekly basis.

In the tertiary level, there are 680 public higher education institutions (HEI) and 1,708 private ones [2]. These educational systems shall reach out to their nearby communities to give meaningful reality to their membership in local and national society and to enrich their civic participation in program undertaking [6]. The Angeles University Foundation-College of Education (AUF-CED), a Center of Excellence (COE)recognized-academic institution among the 36 HEIs identified as COE, realizes that literacy education should not only be delivered within the academic community but may also be integrated through community extension which is one of its threefoldmajor functions to enhance capacity building of its personnel in their field of expertise by way of extending it to the partner community.

The AUF strongly recognizes the vital role colleges and universities play in the development of communities. As a leading institution of higher learning in the province, it is cognizant to the call of the Philippine Grand EFA, a national initiative that promotes alliance through a range of partnerships, collaborations, and linkages among educational stakeholders from the national to the community level to make EFA possible.

In effect, the AUF-CEDis committed to deliver its extension service function with the primary goal of achieving sustainable partnership with the government and private organizations in poverty alleviation and literacy development. One measure to realize this goal is through the implementation of one of the college's extension service projects, Remedial Reading Program (RRP), under the umbrella of Center for Christian Formation and Praxis (CCFP), the University's arm in fulfilling its mandate of social responsibility by conducting altruistic activities anchored on the ideals of rendering selfless service in behalf of others.

The conduct of the AUF-CED community extension project, Remedial Reading Program, hinges on the theory of integrated curriculum or community service learning, the name given to the integration of community service into students' courses. This program provides real-world contexts and problems that enable students to integrate theory and practice in such a way that the community benefits and the students apply theories and skills that are relevant to their future profession [7].

In addition, an integrated curriculum is defined as a collaborative approach involving partners and various disciplines planning and implementing one or more strategies to impact micro and macro systems associated with one or more identified issues [8]. Integrated extension program in particular, is a joint approach (involving two or more disciplines) to planning, delivering, and evaluating multi-faceted strategies for addressing broad community issues. It involves a coordinated effort among educators in community development and the partner community, as well as the merging of resources to meet the needs of the community.

Community involvement pedagogies, often called "service learning," are ones that combine learning goals and community service in ways that can enhance both student growth and the society's welfare. As a teaching and learning strategy, it integrates meaningful community service with instruction and reflection to enrich the learning experience, teach civic responsibility, and strengthen communities. Technically, it is a form of experiential curriculum where learning occurs through a cycle of action and reflection as students seek to achieve real objectives for the community and deeper understanding and skills for themselves. In the process, students link personal and social development with academic and cognitive development; experience enhances understanding; 
understanding leads to more effective and productive action [9].

Typically, community involvement is incorporated into a course or courses by way of a project that has both learning and community action goals. This project is designed via collaboration between faculty and community partners, such as nongovernmental organizations or government agencies. The project requires students to apply course content to community-based activities.

The mode how the AUF remedial reading program is integrated into the course is through the scheme, "required within a course". Under this system, all students must participate in community service as an integral component of the subject or subjects. This feature must be clearly communicated during the orientation or at the first class meeting, on the syllabus, with a clear rationale provided to students as to why the service component is required.

The remedial reading program adopts the best practices in community service teaching by Bandy (2017) [10]. Such principles include curriculum content, community involvement, student reflection, and providing feedback.

Academic content describes the link between the project and the course content. This means that learning goals and community engagement goals should be closely aligned. Content should inform students about various dimensions of their community project and, likewise, community engagement should provide opportunities to learn course content at deeper levels.

Community involvement refers to hands-onminds-on experience or the actual engagement of the learner in the project, in some, if not in every stage of the course, when possible. It is significant to encourage and support community involvement in project planning, student orientation, relevant lectures, site visits, implementation, discussions, progress reports, presentations, and program evaluation.

Student reflection provides opportunities for students to reflect upon their community experience as the learning situation or context of course content. This component serves as the mechanism that encourages students to perceive the relevance and meaningfulness of their course content. Students may be required to complete reflection exercises or tasks such as personal journals, double-entry journal, research paper, case study, portfolio,personal narratives, and weekly log or narrative.
Providing valuable feedback and implementing quality evaluation can create an impact on students' performance and commitment to the project. Both formative and summative evaluations may serve as precaution and yardstick to gauge the success of the program.

In the conduct of the remedial reading program, the AUF-CED adopts Bandy's (2017) implementing procedures composed of four steps: preparation, action, reflection, and evaluation.

Preparation encompasses the establishment of proper mindset in order to face the actual undertaking of the program. It is necessary to provide adequate information on the following: goals, ethics, logistics, and others.

Action is the actual implementation of the project. This phase involves providing syllabi, roles, and schedules to students and community partners, conducting orientation and training to the students, facilitating discussions and processing regular progress reports and assessments of student and project development. This stage may also include regular contact with the partner community, allotting regular reflection and evaluation sessions, and celebrating student and community achievements.

Reflection is the phase that entails analyzing experiences and drawing out meaningful insights from them. In the process of introspection, it may also incur a change of attitude, belief, assumption, prejudices, and stereotypes.

Evaluation of the community project is concerned in determining the degree of achievement of the objectives set. Similarly, it can predict the success of future projects for it may reinforce design and implementation practices.

The AUF-CED extension project focuses on the issue of providing literacy education through remedial reading program as there is a serious widespread problem on difficulty of reading among elementary school children. Studies show that at least one out of five students has significant difficulty in reading acquisition [11]. Similarly, 59\% of fourth grade students are performing below a basic literacy level on standardized reading tests [12].

In Angeles City, Philippines, a survey in public schools revealed that most readers of texts in Filipino and English are in the instructional level. Among these pupils, 10,889 of them are slow readers while 420 are non-readers. In effect, this remedial reading program aims to elevate the level of reading 
literacy of pupils in selected elementary schools in the Division of Angeles City.

Remedial reading program enables people to be successful and effective readers. It is a resource pullout program to provide remedial services to children after they have demonstrated reading difficulty [13]. Providing remedial reading programs is imperative to improve both reading fluency and reading comprehension, particularly to elementary school students because fluency and comprehension are particularly important at the early stage of development and early intervention can impact the progression of reading difficulties.

Literature has shown that remedial reading is an evidenced-based strategy designed to increase reading fluency and comprehension [14]. This method of practice increases language skills and builds general knowledge setting a foundation for basic life skills.Hausheer, Hansen, and Doumas[15] evaluated the effectiveness of a remedial reading program in improving reading fluency and comprehension for elementary school students.

The remedial reading strategy is likely successful because it incorporates feedback from the intervention provider to the student reader. Studies show feedback given during oral reading improves children's word accuracy, reading comprehension and fluency [16]. In addition, students' consistent attendance at the remedial reading sessions produced significant gains in their reading achievement [17]. The prolonged duration of the implementation of the intervention program is for greater impact [11].

More significantly, identifying best practices in reading literacy interventions can increase the reading achievement of the students. Also, implementing best literacy practices and instructional strategies can help improve the literacy development of the student. The findings indicated that an outcomebased curriculum incorporating Bloom's levels of learning coupled with supportive district decisions regarding literacy were key components driving literacy success at the target school [18].

Many studies reported that various practices have been employed to address low literacy achievement including school reform, data-driven decisions, and the engagement of diverse literacy strategies. Some researchers [19] reported that reading aloud to children does help develop comprehension and decoding ability. The positive effects of adult-child reading pairs, where parents got involved in their child's reading activities [20]. Paraphrasing is also a means to improve comprehension [21]. Commonly used strategies that contribute to student self-efficacy in the area of literacy give student choices, empower students and give them ownership of their work [22].

The issue on literacy education and the provision of its related services involve not only the basic education, but also the higher institutions of learning. Thus, the community extension as a thrust of tertiary academic institutions is gaining wider recognition among school administrators and development planners. Extension activities have high potential for contributing quickly and substantially to local and national development [23]. Extension as a function of higher education together with instruction and research help in solving local as well as national problems. The relevance of any university can be defined and measured by the appropriateness of its curricular offerings and the responsiveness of its proclient-community that embraces those within and outside its premises [24].

Contaoi evaluated the effectiveness of the Extension Program of a state university by analyzing the relationship between administrative capability and level of program outputs in terms of skills training, information drive, medical-dental mission, and livelihood organizations. The study was able to establish the favorable impact of the services rendered on economic and social dimensions [23].

In the study of Williams, he determined the effectiveness of the best practices in literacy achievement to address the reading failure of selected elementary schools. The findings indicated that an outcome-based curriculum incorporating Bloom's levels of learning coupled with supportive district decisions regarding literacy were key components driving literacy success at the target school [18].

Figures later assessed the Reading Literacy Extension Program (RLEP) of the University of Northern Philippines through determination and analysis of the reading competencies of the pupil-clients during the implementation of the program and to assess the said program as a whole. Results disclosed that the RLEP was favorably evaluated for it improved remarkably the reading competencies of the pupils and strengthened their reading skills [24].

The preceding literature provides theoretical bases in the conduct of the present study which centers on the implementation of AUF-CED community extension service through the remedial reading program intended for the public elementary school students. The University is aware of the thrust of DepEd which is the development of the basic skills, reading, writing and arithmetic and making every child a reader. 
The remedial program also enhances the preservice training of the AUF-CED student teachers who acted as tutors of the pupils, all of which will contribute to the attainment of quality education in the public school system. Quality education is a constitutional mandate as provided for in Article XIV, Section 2: Philippine Constitution which states that "it is the right of every citizen to receive quality education at all levels, and make education accessible to all."

Accordingly, the AUF-CED aims to provide quality education and maintain excellence through one of its threefold-functions, the extension services along with the provision of impact projects to the community. Hence, this study looked into the extent how the remedial reading program could provide significant contribution to the community and help facilitate assistance in building an over-all image of the university in its pursuit for academic excellence and constant awareness and sensitivity to the clientele needs, thereby improving quality of education and strengthening relationship with the community.

Similarly, the AUF-CED aims to promote cooperation and collaboration with stakeholders like the DepEd and LGUs, build linkage and evaluate progress of such partnership. Hence, the Remedial Reading Program of the University is a worthwhile outreach undertaking provided to the nearby public school community in response to the felt need and urgent concerns of clientele. Assessment in the implementation of this extension program is necessary in order to provide feedback on the said program.

This study aimed to describe the best practices of AUF-CED's remedial reading program, academic year (AY) 2016 to 2017. Specifically, it sought to determine the best practices of the remedial reading program implementing procedure and evaluate its impact among 267 pupil-respondents' reading performance categorized under frustration level as indicated by difficulty in decoding, word recognition, miscues, slow reading speed, and poor comprehension.

\section{RESEARCH METHODS}

The study used the Mixed Methods. To meet the goals of the study, the researchers used quantitative and qualitative approaches to analyze the qualitative and quantitative data they gathered.

\subsection{Participantsand Sampling Technique}

The participants of this study were 267 grade three pupils from six (6)adopted public schools of AUF in Angeles City. They were determined using purposive sampling using QRI-5. Said pupils whose reading proficiency is categorized under frustration level were identified based on the results of the PreTest administered by the third year and fourth year students of the College of Education (CED) under the supervision of faculty members coming from AUFCED and CCFP. Originally,305 pupils were named by their respective schools to take the pre-test. These pupils took the Philippine Informal Reading Inventory (Phil-IRI) administered by their own schools, which identified them as non-readers or readers in the frustration level. Phil-IRI which is conducted annually among Grade 3 pupils nationwide aims to establish the reading level profile of children in the public elementary school system [25]. Using the pre-test from the QRI-5 of Leslie and Caldwell[26] to validate results of the Phil-IRI, the students and the researchers determined the list of pupils who availed of the Reading Remediation Program. The same test was used as post-test.

Table 1.Comparison of Readers in the Frustration Level in the Phil-IRI and in QRi-5

\begin{tabular}{|c|c|c|}
\hline $\begin{array}{l}\text { PUBLIC } \\
\text { SCHOOLS }\end{array}$ & $\begin{array}{l}\text { As per Phil-IRI } \\
\text { data submitted } \\
\text { by the Schools }\end{array}$ & $\begin{array}{l}\text { As per result of } \\
\text { Pre-Test using QRI } \\
5^{\text {th }} \text { ed.(administered } \\
\text { by } C E D)\end{array}$ \\
\hline $\begin{array}{l}\text { Belen Homesite } \\
\text { Elementary } \\
\text { School }\end{array}$ & 25 & 13 \\
\hline $\begin{array}{l}\text { Dr. Clemente N. } \\
\text { Dayrit Elementary } \\
\text { School }\end{array}$ & 128 & 90 \\
\hline $\begin{array}{l}\text { Jose Dizon } \\
\text { Elementary } \\
\text { School }\end{array}$ & 49 & 47 \\
\hline $\begin{array}{l}\text { Marisol Bliss } \\
\text { Elementary } \\
\text { School }\end{array}$ & 63 & 42 \\
\hline $\begin{array}{l}\text { TeodoroTinio } \\
\text { Elementary } \\
\text { School }\end{array}$ & 50 & 39 \\
\hline $\begin{array}{l}\text { Virgen Delos } \\
\text { Remedios } \\
\text { Elementary } \\
\text { School }\end{array}$ & 43 & 36 \\
\hline TOTAL & 358 & 267 \\
\hline
\end{tabular}

The QRI-5 is a test containing authentic materials for emergent to advanced readers. It is nonstandardized but it is research-based, easy to administer, and diagnostic. It contains several levels but the researchers chose pre-primer considering the recommendation that the pre-test must be two levels lower for pupils with difficulty. The pre-primer test measures reading accuracy, rate, and comprehension. It 
has 17 words in the word listpresented using individual flash cards and 37 words in the narrative titled "I Can". There are five explicit questions in the comprehension test. The mode of reading was oral. The student-tutor read the comprehension questions. To record the performance of the pupils, student-tutors used a scoring sheet (Appendix A) and audio recorder which partly determined the impact of the program. QRI-5 served as test for con-current validity for Phil-IRI.

Also, during the conduct of the remediation, student-tutors used lesson plans that focused on sounds particularly on consonant sounds, vowel sounds, onsets, rimes, clusters, and diphthongs. They prepared the plans in groups and attached all instructional materials needed. Discussion and improvement of content of the plan was done in the class of third year and fourth year English majors.

\subsection{Data Collection Procedures}

Guided by the Memorandum of Agreement forged between AUF and DepEd in 2015, a three-year Reading Remediation Program is designed for the six public elementary schools in Angeles City located within AUF's vicinity. Pupils who were categorized as non-readers and under frustration level as per the result of the Phil-IRI, a total of 358, were given the pre-test from QRI-5 administered by third year and fourth year students who were given orientation and training in the conduct of the pre-test assessment tool. All participants of the program including teachers and heads of AUF and the participating elementary schools and DepEd officials attended the orientation for the stakeholders. The pre-test was conducted in assigned classrooms of the elementary schools involved.

After the pre-test, 267 pupils were included in the list of the final tutees who were assessed to be in need of the intervention was. Remedial sessions commenced completing 14 sessions starting October 2016 until March 2017 which were held every Friday for two hours $(1: 00-3: 00 \mathrm{pm})$. The post-test was administered by the fourth year students the next Friday following the last session. From the 267 tutees, 166 completed the intervention and took the post-test.

The manpower resource included in the implementation of the Program consisted of the CCFP, CED, Center for Research and Development (CRD), and Non-Teaching Personnel of the University who assisted the student-tutors every session designated in each school. There were a total of 19 third year student-tutors, particularly English majors, and 71 student-tutors from the fourth year. These studenttutors were Bachelor of Elementary Education with area of specialization in Special Education and Bachelor of Secondary Education major in Biological Sciences, English, Filipino, Mathematics, Music, Arts, Physical Education, and Health (MAPEH), and Social
Studies. All of whom were considered primary tutors who conducted actual teaching of four pupils (ratio: 1:4). Their integration in the Reading Remediation Program of the University served as their compliance in the 40-hour community service imperative in Teacher Education Curriculum as part of their service learning. Lastly, there were 38 students, sophomores from different colleges, enrolled in the National Service Training Program (NSTP) under the Literacy Training Service (LTS) component, who served as assistant tutors to the primary tutors (ratio: 1:2). School assignment was dependent on the number of pupils who availed of the program. Students spent for their own transportation fare while CCFP shouldered the reproduction of lesson plans and instructional materials. The Reading Remediation Program Implementation Procedures and Logistics for served as the blue print in determining the scope and extent of responsibility of each of the group of people involved in the program.

LTS students together with the student-tutors also monitored and filed the attendance, evaluation scores, and over-all evaluation of both the primary tutors and the LTS student on the progress of each tutee. These reports by LTS students were then consolidated by the NSTP teachers using Consolidated Reading Remediation Monitoring Report. Moreover, periodic assessment meetings and focus group discussions were held by the proponents and the tutors to assess the effectiveness of the implementation processes.

Meeting with heads of the adopted schools and Focus Group Discussion (FGD) initiated by the CCFP were conducted to report the results, progress, and feedback of the implementation of the program. This formed part of the assessment process of the Literacy Program.

\subsection{Data Analysis}

The researchers used qualitative approach in identifying the best practices gathered during the FGD and mean to describe the scores, standard deviation to describe how dispersed the scores were from the mean, and $t$-test to determine if there was significant difference between the pretest and the post-test scores.

\section{RESULTS AND DISCUSSION}

\subsection{Best Practices}

\section{Integration of Service Learning in the Curriculum}

The program served as avenue for the studenttutors to see the theories they learned in their different general education, professional education and specialization courses come to life through actual practice. Le Bontef (as cited in Opazo, Aramburuzabala, and Cerrillo, 2016) mentioned that in 
order to train professionals to manage complex situations, it is necessary to use innovative teaching proposals that help integrate theory and practice [27]. Among the courses integrated are Christian Formation 1 and 2, NSTP, Principles of Teaching 1 and 2, Developmental Reading 1 and 2, Assessment of Learning 1 and 2, Practice Teaching, Preparation and Evaluation of Instructional Materials, Remedial Instruction in English, Teaching of Listening and Reading, and Instrumentation. The student-tutors had first hand and hands-on experiences in lesson planning, classroom management, actual teaching and evaluation, and research. They engaged in reflective teaching or metacognition as noted by Bandy [10]. Also, the program enabled the year IV student-tutors to complete 40 hours of their required community service and the second year students to comply with their requirements in NSTP LTS. The program also made possible for AUF to assist faculty to integrate and implement service learning in their courses. Anderson (as cited in Philips, Bolduc, and Gallo, 2013) gave examples of several teacher preparation programs integrating service learning in the curriculum to make it part of the skill-based repertoire possessed by beginning teachers [28]. The meaningful integration support provided by the faculty in the program may be considered one of the examples.

\section{Active Engagement of Stakeholders}

The program is one of the many opportunities for the faculty, students, and non-teaching personnel (NTP) to collaborate. In the program, CCFP crafted the MOA and the logistics including close coordination with the heads and teachers of the six schools especially on schedules and venues. They also commissioned faculty and NTP who accompanied the student-tutors to the assigned schools, sponsored the reproduction of materials, and gathered stakeholders during meetings. The College of Education spearheaded the orientation of student-tutors on the pretest, the preparation and improvement of lesson plans, the assignment of students to the elementary schools, and the processing of the teaching-learning experiences of the student-tutors. The NTP volunteered to accompany student-tutors to the elementary schools and coordinated with the heads and teachers of schools on any concern. All rendered service pro bono. The commendable service is also seen in Bandy's work [10] and described as impactful to the community being served [8].

The DepEd supported the program by signing the MOA and meeting all principals to orient them on this important project. More importantly, the adopted elementary schools headed by their officers in charge or principals also made possible the conduct of the program by gathering the pupils, providing venue, and encouraging pupils and parents to participate. They also allotted Friday afternoon for the program.

Overall, all stakeholders benefited from the experience as teaching and learning were integrated in the program.

\section{Contribution to AUF's Thrust and Quality Objective}

One of the mandates of AUF as a higher education institution is community extension service which the program contributed to. The program is one of numerous efforts to reach out to the community near AUF by adopting schools and addressing one of its needs, reading remediation. The program seconds the conduct of regular remedial classes of the adopted schools.

In addition, AUF aims to involve $100 \%$ of its faculty and $95 \%$ of its students to community service. Through the program, faculty and students were invited anew to reach out as emphasized [7]. The program functioned as means to attain the objective as teachers capacitated the student-tutors and readied them for this project. Students also participated and practiced their future profession in a meaningful and sustainable manner. This coincides with the findings of MartinezOdria (as cited in Opazo, Aramburuzabala, \& Cerrillo, 2016) who maintains that students experience selfknowledge when they put into practice the knowledge that they have gained in the classroom. Findings in the study of Opazo, Aramburuzabala, and Cerrillo (2016) showed the positive effects of service learning in the improvement of personal and professional development of the students [27]. This implies that commitment is developed beyond teaching when service learning is integrated in the curriculum.

\subsection{Impact of the Program}

The table below shows the mean of the scores the pupils earned during the pre-test and the post-test. As shown, pupils improved in the number of words correctly read in the list, out of 17 given words $(7.8<12.45)$ also with decreasing standard deviation (SD) meaning scores were less dispersed from the mean during the post-test. The difference in the scores in the number of words correctly read in the list is significant since the p-value is lower than the alpha (alpha=0.05). 
In terms of the number of words correctly read in the text with 37 words, a leap from a mean of 13.10 words during the pretest to 31 during the posttest was recorded along with the lowered SD in the post-test. There is a significant difference in the pretest and post-test scores of the number of words correctly read in the text.

When it comes to miscues, the number decreased from 8.38 to 6.76 also with less dispersed scores during the post-test, meaning the scores were closer to the mean. However, the difference between the two means is insignificant or higher than the alpha (0.570). The identified miscues were mispronunciations including addition of sound or syllable and omission of sound or syllable, reversal of letters or syllables, guessing, finger pointing while reading, and self-correcting but still incorrect reading. This coincides with the study of Khalid, Buari, and Chen (2017) which results revealed that mispronunciations and substitutions were the most possible types of errors made when reading [29]. Because of lack of expertise, student-tutors did not count the exact number of miscues per category.

Out of the five comprehension questions whose answers are explicitly found in the text, a mean of 1.36 was answered during the pre-test and a mean of 3.82 in the post-test with less dispersed scores in the post-test. Since the p-value is lower than 0.05 , there is a significant difference between the pre-test and posttest scores in the reading comprehension component of the test. This finding resembles other cited works $[13,14,15]$.

In terms of reading rate computed through correct words per minute, pupils read a mean of 18.85 words during the pre-test and almost doubled their rate (30.38) during the post-test. Still, pupils did not meet the expected speed of 80 words per minute. Again, scores were less dispersed from the mean during the post-test, yet there is no significant difference in this component with the p-value of 0.179 . The mentioned results contradict those indicated as programs that promoted fluency $[14,15]$.

Significant differences in three out of the five components (accuracy in reading word list and words in the text and comprehension) signaled gains in reading competencies [23].
Table 2. Comparison of Pre-test and Post-test Results

\begin{tabular}{|l|r|r|r|r|r|}
\hline \multicolumn{1}{|c|}{ Item } & $\begin{array}{c}\text { Pre- } \\
\text { Test } \\
\text { Mean }\end{array}$ & SD & $\begin{array}{c}\text { Post- } \\
\text { Test } \\
\text { Mean }\end{array}$ & SD & p-value \\
\hline $\begin{array}{l}\text { Words } \\
\text { correctly read } \\
\text { in the list }\end{array}$ & 7.80 & 6.12 & 12.45 & 5.20 & 0.000 \\
\hline $\begin{array}{l}\text { Words } \\
\text { correctly read } \\
\text { in the text }\end{array}$ & 13.10 & 13.99 & 31.00 & 9.38 & 0.000 \\
\hline $\begin{array}{l}\text { Number of } \\
\text { Miscues }\end{array}$ & 8.38 & 10.71 & 6.76 & 8.78 & 0.570 \\
\hline $\begin{array}{l}\text { Comprehension } \\
\text { questions } \\
\text { correctly }\end{array}$ & 1.36 & 1.56 & 3.82 & 1.46 & 0.000 \\
\hline $\begin{array}{l}\text { Correct words } \\
\text { per minute }\end{array}$ & 18.85 & 26.79 & 30.38 & 21.90 & 0.179 \\
\hline
\end{tabular}

The student-tutors kept their journals in which they noted observations which revolve around some themes such as the learners' attitudes, the learners' difficulties, and the learners' improvements. Below are actual journal entries that are categorized by the stipulated themes.

\section{Learners' Attitude}

The tutors noticed the way the pupils behaved which affected the program especially in terms of attendance. Some learners were described as "quiet," or "talks a little" if not "shy," "talkative,"or "distracted." What distracted the pupils are "classmates," their desire to play "'games," and their domestic responsibility such as fetching water. On a positive note, the tutors considered the pupils "active," responsible," and "participative." The tutors also acknowledged what the pupils needed such as "serious[ness] on [in] learning," "guidance," "improve[d] attention," "practice and dedication, "and "confidence." Tutors, therefore, responded by innovating and encouraging the pupils to participate through activities and simple rewards like "praise words."

\section{Learners' Difficulties}

In general, pupils could read in Filipino but found English words perplexed. Among the difficulties singled out were with "sounds of letters" specifically "words with "ai' in the middle," "y and a," "the sounds of $i$ and e," "diphthongs," and "[consonant] blends." Some were troubled by rimes such as "ab, ag, and at." With words, they struggled with "joined [compound] 
words," "rhyming words," and "difficult [multisyllabic] words." Ney, in his study, "A Comparison of Reading Miscues and Writing Miscue" found that the miscues of addition and substitution are more frequent in reading and that evidence from the phonological/pronunciation miscues in reading supports the Chomskian theories about the relation of the sound structure of English to the orthography [30]. Some also had problems with "following instruction[s]," making them read slowly if not incorrectly. To address these concerns, tutors gave more exercises and devoted more time on some lessons; hence, they were unable to be on schedule. These same difficulties are stated in the studies [11,12] cited above.

\section{Learners' Improvements}

Towards the end of the program, tutors wrote entries signaling multi-faceted improvement. In reading in particular, they wrote "he is able to read properly" and "continue to improve her reading skill." In terms of general performance in the program, tutors shared that the pupils were "almost perfect in activities" and "can easily understand the lesson." More specifically, one tutor inscribed that her pupil "answers the exercise so easily." In terms of attitude towards the lessons, the pupils also showed advancement as tutors penned that they "[were] participating when the teacher is teaching," "he follows me generously [religiously]," "exert effort vigorously," "he improves[d] his confidence," and that they became "more focus[ed]" or "concentrated," and "more expressive" from being shy or quiet. All these statements underscored overall reading achievement similar to the one discussed on top [16]. The pupils increased confidence also affirmed the appropriateness of the strategies applied [21].

During the FGD, student-tutors also noted their joy for being able to share to the community, practice their craft, meet and network with teachers and school heads, and manifest values such as patience, resourcefulness, flexibility, determination, and generosity. Some shared more than their time and knowledge but also their resources in the form of prizes to and additional reading materials for their pupils. They also expressed regret for the short duration of the program and difficulties mostly related to the absenteeism of pupils, cancelled class schedules because of other school activities and calamities, and inclusion of some pupils who were not part of the program.Results would have been better if tutees regularly attended the sessions since attendance is a contributory factor to learning [16].

Considering the forgoing results, the researchers conclude that the reading remediation program paved way for AUF to continually do its best practices through its arms AUF-CED and CCFP. Also, the program has strong impact considering the significant differences in the components number of words correctly read in the list, number of words correctly read in the text, and number of comprehension questions answered correctly.

The researchers also recommend the continuation of the program, its longer implementation as recommended [10], the involvement of more schools, the adoption of the response to intervention model, the same assigned school during the pre-and post-tests and the actual teaching, and the participation of more Education students. Moreover, a training model that promotes in its practice teaching learning and research be designed by each university to properly integrate professional and socially responsible practice in the curriculum [27]. Service learning may also be matched according to students' level of maturity and personal development stages [28] as was done by AUF CED by selecting only third and fourth year students to act as student-tutors.

\section{References}

[1] Worldometers, "Philippines population 2017", Retrieved from www.worldometers.info/world_population/ph ilip, 2017.

[2] L. Cristobal, "Literacy in the Philippines: The stories behind the numbers." https://www.literacyworldwide.org/blog/litera cy-daily/2015/08/06/literacy-in-thephilippines-the-stories-behind-the-numbers

UNESCO. 2013. "National EFA review guidelines." Retrieved from http://unesdoc.unesco.org/images/0022/00222 4/222445E.pdf

[4] Education for All 2015 National Review Report: Philippines. http://unesdoc.unesco.org/images/0023/00230 $\underline{3 / 230331 e . p d f}$

[5] UNICEF, "The state of the world's children 2016, Retrieved from https://www.unicef/publications/files/UNICE F SOWC 2016, 2017.

[6] H. S. De Leon, "Textbook on the Philippine Constitution.’REX Book Store. Manila, Philippines. 2008.

[7] E. Parker, N. Myers, H. Higgins, T. Oddsson, M. Priceand T. Gould,"More than 
experiential learning or volunteering: A case study of community service learning within the Australian context,"Higher Education Research and Development, 28(6), 585-596, 2009.

[8] K. DeBord, "How Integrated Extension programming helps market Cooperative Extension: The North Carolina recommendation," Journal of Extension [Online], 45(5) Article 5COM1. Retrieved on September 2010 from http://www.joe.org/joe/2007october/comm1.p $\underline{\mathrm{hp}}, 2007$.

[9] Clinton and Thomas, "Business students' and community service learning," Asia-Pacific Journal of Cooperative Education, 12(1), 5166, 2011.

[10] J. Bandy, Center for Teachinghttps://cft.vanderbilt.edu/guides-subpages/teaching- through-communityengagement, 2017.

[11] W. J. Therrien, "Fluency and comprehension gains as a result of remedial reading. Remedial and Special Education, 25, 252-261, 2004.

[12] M. B. Calhoon, "Effects of a peer-mediated phonological skill and reading comprehension program on reading skill acquisition for middle school students with reading disabilities. Journal of Learning Disabilities, 38, 424-433, 2005.

[13] Snow, K. Snow, M. S. Burns, \& Griffin, P. Griffin, (Eds.), "Preventing reading difficulties in young children." National Academy Press, Washington DC, USA., 1998.

[14] P. McCardle, H.S. Scarborough, \& H. W. Catts, "Predicting, explaining, and preventing children's reading difficulties", Learning Disabilities Research and Practice, 16, 230239, 2001.

[15] R. Hausheer, A. Hansen, D. M. Doumas, "Improving reading fluency and comprehension among elementary students: Evaluation of a school remedial reading program,"https://www.literacyworldwide.org/ blog/literacy-daily/2015/08/06/literacy-in-thephilippines-the-stories-behind-the-numbers, Boise State University, 2011.

[16] L. K. Crowe, "Comparison of two oral reading feedback strategies in improving reading comprehension of school-age children with low reading ability, Remedial and Special Education, 26, 32-42, 2005.

[17] K. S. Anderson, "The efficacy of a reading rmediation program for ethnical and economically diverse at-risk readers," Graduate Degree1 Major: Ed.S. in School PsychologyResearch, May, 2006.

[18] R. B. Williams, "Best practices in literacy achievement to address reading failure for elementary schools in one school district," 2016.

[19] T. Zucker, L. Justice, \& S. Piasta, "Prekindergarten teachers' verbal reference to print during classroom-based, large-group shared reading", Language, Speech \& Hearing Services in Schools, 40, 376-392, 2009.doi:10.1044/0161-1461(2009/08-0059)

[20] A. Cadieux and P. Boudreault, "The effects of a parent-child paired reading program on reading abilities, phonological awareness and self-concept of at-risk pupils", Psychological Reports, 42(4), 224-237, Retrieved from ERIC database. (EJ764822), 2005.

[21] S. Kletzien, "Paraphrasing: An effective comprehension strategy", The Reading Teacher, 63, 73-77, 2009. doi: 10.1598/RT.63.1.7, 2009.

[22] B. Walker, "The cultivation of student selfefficacy in reading and writing", Reading \& Writing Quarterly, 19, 173-187, 2003. doi: $10.1080 / 10573560308217$

[23] M. R. Contaoi, "The effectiveness of the extension program of the University of Northern Philippines," (Unpublished Master's Thesis, University of Northern Philippines, Vigan City, Ilocos Sur), 2003.

[24] O. B. Figuerres , UNP Research Journal, University of Northern Philippines

UNP Research Journal, Vol. XX, JanuaryDecember 2011.

[25] Manual and User's Guide for Phil-IRI, Bureau of Elementary Education, Department of Education, accessed August 18,2017 at https://depedkoronadalcity.files.wordpress.co m/2012/10/phil-iri-manual-and-usersguide-for-school-users.pdf, 2009. 
[26] L. Leslie and J. S. Caldwell. "Qualitative Reading Inventory $5^{\text {th }}$ Ed." USA: Pearson, 2011.

27] H. Opazo, P. Aramburuzabala, and R. Cerrillo. "A review of situation of servicelearning in higher education in spain." AsiaPacific Journal of cooperative Education", 17, 75-91, 2016. Files.eric.ed.gov/fulltext/EJ1114040.pdf

[28] A. Phillips, S. Bolduc, \& M. Gallo. "Curricular placement of academic servicelearning in higher education."Journal of
Higher Education Outreach and Engagement, 2013. https: eric.ed.gov/?id=EJ1114040

[29] N. Khalid, N. Buari, \& A. Chen. "Comparison of oral reading errors between contextual sentences and random words among schoolchildren." International Education Studies, v10 n1 p47-55 2017.

[30[ J. Ney. "A Comparison of reading miscues and writing miscues." web.a.ebscohost.com/ehost/detail/detail?vid=7 $\&$ sid $=39 \mathrm{ca} 0541-3 \mathrm{bf5}-491 \mathrm{c}-8 \mathrm{~cd} 1$ $\mathrm{d} 439 \mathrm{c} 00 \mathrm{~d} 1 \mathrm{~d} 00 \% 40$ sessionmgr4009\&bdata $=\mathrm{Jn}$ NpdGU9ZWhvc3QtbGl2ZQ\%3d\%3d\#AN=E D161009\&db=eric. 